Article

\title{
The Federal Features of the EU: Lessons from Canada
}

\author{
Amy Verdun \\ Department of Political Science, University of Victoria, Victoria, BC V8W 2Y2, Canada; E-Mail: averdun@uvic.ca
}

Submitted: 22 February 2016 | Accepted: 30 June 2016 | Published: 11 August 2016

\begin{abstract}
There has been a rise and fall in interest in federalism in the context of European integration. This article assesses the federal nature of the EU. It draws in particular on the work of Michael Burgess who has been one of the key thinkers on this issue. Because there are many types of 'federalisms' available across the globe, it is helpful to make a comparison with another political system to offer a base line. In this article I explore to what extent the EU already has federal features. With the help of the work of Burgess I seek to look beyond the specific characteristics of the EU and reflect on how a comparison with this other polity can offer us insights into what is going on within the EU political system. Drawing on the comparison with Canada, I seek to identify the characteristics of the EU that are already those of a federation. Therefore, the guiding question of this article is: compared to Canada, what particular features does the EU have that reminds us of a federation and what features is it still lacking? It finds that the EU has a considerable amount of federal features (federation), but that a federal tradition, a federal ideology and advocacy to a federal goal (federalism) are mostly absent.
\end{abstract}

\section{Keywords}

Canada; Canada-EU comparison; European Union; federalism; federation; political system

\section{Issue}

This article is part of the issue "Supranational Institutions and Governance in an Era of Uncertain Norms", edited by Russell Alan Williams (Memorial University, Canada) and Reeta Tremblay (University of Victoria, Canada).

(C) 2016 by the author; licensee Cogitatio (Lisbon, Portugal). This article is licensed under a Creative Commons Attribution 4.0 International License (CC BY).

\section{Introduction}

The European Union (EU) is typically categorised as an international organisation. For instance, the Union of International Associations (UIA), founded in 1910, states on its homepage: "an Intergovernmental Organization IGO is an organization composed primarily of sovereign states, or of other intergovernmental organizations. IGOs are established by treaty or other agreement that acts as a charter creating the group. Examples include the United Nations, the World Bank, or the European Union" (UIA, 2015). ${ }^{1}$ Following this definition it is easy to see that the EU indeed is an international organisation - the founders and subscribers

1 The UIA subdivides 'international organizations' into three categories namely: inter-governmental organizations, international non-governmental organizations, and multinational enterprises. are sovereign nations and it is based on a treaty.

At the same time, those who have studied the EU more closely would not have any difficulty identifying the EU's state-like features. William Wallace famously characterised the European Community (EC), at the time, as 'less than a federation; more than a regime' (Wallace, 1983). Since then, the EC has evolved into the European Union (EU) but Wallace's characterisation still resonates with many scholars today (see Joerges, 2005, p. 14). In fact, over the past two decades, when forced to categorise what kind of political system the EU is, we find many that characterise the EU as being 'sui generis' in some form or other (for an overview see Phelan, 2012, who seeks to understand this issue from an International Relations perspective). Ingeborg Tömmel (2012) offers a nice comparison of the EU with ideal type federations and concludes it is not a fully-fledged federation; she does not expect it to 
become one in the near future, yet she finds that it does have some characteristics of a federation. She thus names the EU 'a federation sui generis' (Tömmel, 2011). John-Erik Fossum (2006) also seeks to impose some discipline on exactly how the $\mathrm{EU}$ is a sui generis polity. He differentiates between those who see the EU as departing from a nation-state, those that see it as part of state withering or transnationalization, those that view it as a case of nation-state transformation, or as a subset of fledgling states.

In light of the above brief discussion of the key concepts of intergovernmental organization versus federation what would it take for the EU to resemble more a federation than an international organisation? Very few scholars of European integration have been so bold as to state that the EU is already starting to resemble a federation. ${ }^{2}$ Yet one could list a number of characteristics of the EU that overlap with those of federations. Thus, I pose the question in this article: what particular features does the EU have that reminds us of a federation and what features is it still lacking? I am posing this question because the answer to this question will shed light on the amount of federal development achieved in the EU, but also where this development falls short of a possible yardstick, both theoretically and in comparison to an existing case. Specifically, this article seeks to study this question theoretically by examining the concept of federalism and federation drawing on Europeanist literature on federalism, in particular through the work of Michael Burgess. It also offers a concrete comparison with an established federal state, Canada, as an example of a federal state. I am not the first to make a comparison between the EU's development to that of another federal state. However, most scholars who have embarked on such a comparison have tended to concentrate on the comparison with the United States (US). As David McKay points out, it is the political system that most resembles the $\mathrm{EU}$ in terms of its size, and political and economic development (McKay, 2001, p. 4). ${ }^{3}$ I have chosen to concentrate on Canada rather than the US, not only because the comparison with the US is well documented in the literature and not terribly successful (Hueglin, 2013). Rather, because at the end of the day the EU needs to deal with multinationalism (as does Canada). ${ }^{4}$ Furthermore, Canada is a much more

\footnotetext{
2 Examples of scholars who have described the EU this way see Kelemen (2003, 2007), Hueglin (2013), Börzel and Hosli (2003), Börzel (2005), Kreppel (2006) and Verdun (2015a). Wood and Verdun (2011) have compared Canada and the EU, thereby implicitly examining the EU as a federal-like entity, see for their more recent studies: Verdun and Wood (2013). Others who have made this explicit comparison are, among others, Simeon (2006), Wolinetz (2011), Hueglin (2013).

${ }^{3}$ For others who have made the comparison with the US see in particular Fabbrini (2005) and Menon and Schain (2006).

${ }^{4}$ Multinationalism in Canada has various characteristics, in-
}

decentralised federation than is the US and for the foreseeable future the EU-version of federalism would need to maintain those features. Also the experience with US politics is more idiosyncratic with its strongly polarised two party system. Finally, seen that the US has developed as one of the world's superpowers also gives that country a unique role in global politics. This superpower status, over time, has reinforced executive power in a way that is different in a country such as Canada that has a less forceful stance in the globe. Also, both the Canada and the US constitutions are subject to occasional challenges before the courts. But in the United States the courts have tended to widen federal and narrow state powers whereas the opposite has typically occurred in Canada (Parliament of Canada, 2016). For all these reasons a comparison with Canada rather than the US is much more attractive for the purposes of seeking to understand how much the EU already resembles a federation. The remainder of this article is thus structured as follows. In section 2 I provide a literature review of EU scholars who have examined the question of federalism in the EU context. In the third section I assess what federalism is; in the subsequent section I examine what federalism means in Europe; next I look at what federalism is in Canada; then I offer a comparison of the two systems (Canada and the EU) in the penultimate section; and offer some conclusions in the final section.

\section{The Federalist Political Thought in the EU and the Work of Burgess}

The early developments, post Second World War, were inspired by federalist thought, and were brought forward by people such as Altiero Spinelli (Glencross, 2009; Glencross \& Trechsel, 2010; Pinder, 2007) and Jean Monnet (Duchêne, 1994; cf. Triandafyllidou \& Gropas, 2015). Federalist ideas had been around for centuries, of course, but there was not a unified view on federalism as conceptualised by $16^{\text {th }}$ and $17^{\text {th }}$ century political philosophers, in particular Johannes Althusius and Jean Bodin. In the 1960s, scholars, for example Riker (1964), were influential in streamlining some of this diversity but at this time the federalist thought was less prominent in the EC. Burgess (2000) points to how the federalist thought of Althusius and a later philosopher, Proudhon, left more room for overlapping, divid-

cluding even the perhaps banal issue of having more than one official language. The Canadian constitution stipulates that every province (except Quebec, New Brunswick and Manitoba) may decide which their official language is or if it wants more than one official language (and those need not necessarily be either English or French). In the case of Quebec, New Brunswick and Manitoba, however, the requirement is that as long as English and French are at least part of those official languages they could add one or more official languages (see Parliament of Canada 2016). 
ed and shared sovereignty rather than the conception of federalism à la Bodin (Burgess, 2000, p. 14). Even if there were numerous federalist political thinkers with not always completely overlapping ideas, federal ideas were at the heart of the proposals to pool sovereignty, transfer sovereignty to the supranational level and to limit some national sovereignty.

Students of European Studies sometimes ask the question of the EU's finalité-what exactly will the EU become, with as an important follow-up question, is the EU developing into a federal state? If so, would it be created with a big bang or more incrementally? This vision of a 'big bang' was held by some during the Convention on the Future of Europe, which took place between December 2001 and July 2003 that ended in the creation of the Treaty Establishing a Constitution for Europe, which ultimately failed. ${ }^{5}$ Others have held that European integration has always been and is likely to remain, for the foreseeable future, a gradual process. Through incremental development integration would deepen, and in so doing at some point end up being more like a federation (see Borrell, 2015; Duff, Pinder, \& Pryce 1994). Given that process, the question would be, when would one identify the EU as actually being a federation?

Seeking an answer to this question is one of the reasons for concentrating on the work of Michael Burgess-a scholar who has brought together political thought on federalism and its application to the EU (and federations across the globe). In Federalism and European Union Burgess provides an overview of federal thinking in the EC from 1972-1987 (Burgess, 1989) - a period just before the relaunch of European integration in the early 1990s. In 2012 Burgess wrote about this revival period in the early 1990s: "The ratification of the Treaty on European Union...underlined

\footnotetext{
${ }^{5}$ The Treaty Establishing a Constitution for Europe failed due to a host of reasons, but not in the last place because the ambition of the leaders of the Convention incrementally added more symbolic features to the proposed revised EU constitutional structure that made it look more like a federation-something that in the end did not find sufficient support among citizens. The Heads of State or Government signed off on the text, but at the end of the day the ratification of that particular text stranded following the outcomes of the referendums in France and the Netherlands, where a majority voted against approval of the ratification of constitutional treaty. People were concerned about the labels used to describe the changes, such as the word 'constitution' in the title (see Hobolt, 2006). It also was a very difficult document for every day citizens to understand. With some delay the more 'symbolic' features were removed and essentially a 'watered-down version' (Verdun, 2013) eventually became the Lisbon Treaty, signed in December 2007, which was ratified and entered into force on 1 December 2009 (see for more details about the changes in decision-making before and after Lisbon a collection of papers in Hosli, Kreppel, Plechanavová, \& Verdun, 2015).
}

the federal trajectory of European political integration and paved the way a decade later for the European Union (EU) to prepare the practical proposal for a Constitutional Treaty, subsequently replaced in 2007 by the Lisbon Treaty which was formally ratified in 2009" (Burgess, 2012, pp. 1-2). Later in the same volume Burgess (2012, p. 320) notes: "Rather than adopt one particular approach to federalism, we have suggested that theoretical pluralism is the most profitable way of thinking about the federal spirit". And he also thinks that: "...federalism as a process - the notion of federalizing or federalization - to have the most practical utility when applied to the new federal models....Today federalism as a process offers a convincing explanation of what is happening in...the EU" (Burgess, 2012, p. 320). Michael Burgess's interest in federalism extended much more widely than merely the study of Europe and European integration. In 1990, he edited a volume that examined federalism in Canada (Burgess, 1990). This work was followed soon after by another book on Canada, co-edited with Alain-G. Gagnon (Burgess \& Gagnon, 1993). ${ }^{6}$ His study of Canada is another reason to draw on Burgess in this article.

\section{Federalism-A Concept}

The concept of federalism is different from that of federation (Burgess 1986; Burgess \& Gagnon, 1993, p. xiii; Gagnon, 2010, p. 3; Gagnon, Keil, \& Mueller, 2015; King, 1982). The latter refers more to institutions; the former is broader and includes traditions, ideology including perhaps the advocacy for an end goal. Gagnon differentiates between 'territorial' and 'multinational' federations. The former seeks to treat all citizens the same and have representation by territory (a classic example being the United States) (cf. Burgess, 2006b). A multinational federation acknowledges the existence of various nations within the federation and realizes it needs to accommodate these different minorities (e.g. Belgium, Canada) (Gagnon, 2010, p. 5).

In Comparative Federalism, Burgess provides his insights on what federalism is (Burgess, 2006a). He stresses it has both an empirical and theoretical dimension and is multi-faceted which makes it difficult to have a full-fledged theory of federalism (Burgess, 2006a, pp. 1, 4). He defines federalism as: "the active promotion of support for federation" (Burgess, 2006a, p. 2) with federation being "a particular kind of state" (Burgess, 2006a).

Simplifying a thorough review of the literature that he provides in his study, one could summarize his views on the matter as follows. Federalism is a suitable

\footnotetext{
${ }^{6}$ Burgess at this time also produced an important book on the UK, which focused on the British tradition of federalism, which was very timely indeed as the UK was contemplating devolution in the 1990s (Burgess, 1995).
} 
form of government when a number of circumstances come together. Following Edward Freeman he points to federation being a mechanism of compromise between opposing forces. (Burgess, 2006a, p. 13; cf. Freeman, 1893). He acknowledges that a federation is often chosen as the political system as a deliberate choice (it is artificial), constructed (but based on some kind of reason) and its contours depend on circumstances (the context and the issues of the day will determine its exact features). For an assessment of the merits of federalism he draws on Bryce (1928). These advantages range from "uniting commonwealths into one nation under one government without extinguishing their separate administrations, legislatures and local patriotism" and "the best means of developing a new and vast country" to "facilitating self-government" and enabling people to "try experiments in legislation and administration which could not be safely tried in a large centralized country" and that having local legislatures with large powers would relieve the federal legislature from functions that could prove too heavy for it (Burgess, 2006a, pp. 15-16).

Furthermore, borrowing from the moral philosopher Henry Sidgwick (1891), he points to another major issue in federalism, namely that there is rarely a clear demarcation between the unity of the whole and the separateness of the parts. Thus, one should recognize that federalism would be realized only to different extents (Burgess, 2006a, p. 21). Finally, he posits that there has not really been a sufficient pool of experiences, in the first 30 years after World War II, to develop a single 'theory' of federalism (Burgess, 2006a, p. 45). Rather one should focus on two related factors: (1) the degree of independence of the (two) levels of government; and (2) whether the (two) levels of government can neither subordinate the other to it, nor act completely independent of the other in a range of policy areas (Burgess, 2006a, p. 45).

Applying his insights on federalism on two cases discussed in this article he comes to the following insights: the Canadian case was one in which federalism suited because it served as a way to overcome: (1) the political stalemate in the province of Quebec; (2) the proximity of the United States (possible threat thereof as well as wanting to be a separate from it); and (3) forming a national unity (Burgess, 2006a, pp. 84-85). In Canada the creation of a federal state emerged without too much controversy in two conferences (Charlottetown and Quebec in 1864; and in 1866 in London). Clearly Canada fits the broad description of being a country that was vast, wide, and new and thus federalism could serve well.

Burgess analyses the EU in federal context in two major books (Burgess, 1989, 2000). In each of these books he draws parallels between developments in the EU context and those in the area of federalism. In his 2006 book Burgess devotes a chapter to "The European
Union as a Federal Model". In fact Burgess points to the fact that the EU does not fit a proper understanding of a federation and thus ends up being a "a new kind of federal model the like of which has never before been seen" (Burgess, 2006a. p. 226). He stresses that the process is slow, incremental and lacks big foundation moments. To understand the EU as a federation one needs to understand some of the peculiarities of the EU to which I now turn in the next section.

\section{What Federalism Means in Europe}

Burgess argues that the EU is a unique federal model. The characteristics include that it was built by founding fathers that saw the EU as needing to be a response to the devastation of having had many wars between countries such as Germany and France. Richard Griffiths spells out emphatically that the exact genesis of the $\mathrm{EC}$, in particular the role of the founding fathers, was much more the result of the politics of the day, than the specific visionary characteristics of its founders (Griffiths, 2012). Perhaps the most well-known of them, the Frenchman Jean Monnet, who incidentally travelled through Canada as a young man (Ugland, 2011), saw the interrelation between economics and politics as key to setting up more integration in Europe. But rather than starting off building a federation, as a great visionary goal, he commenced with supranational governance of policy areas that were less political: coal, steel, atomic energy and eventually the creation of an internal market. He also included a defence community, but that plan stranded, as it did not find support in the French parliament at the time. Monnet's method was to focus on a cumulative process of integration: a step-by-step approach. Monnet thought that the big federal moment would come gradually after functional increase of supranational policies (Burgess, 2006a, p. 231). Italian political theorist Altiero Spinelli, another key figure in Europe's past, disagreed with this implicit sense of automaticity in the Monnet method. He felt it was important to organize political power at the European level. But Spinelli, in turn, underestimated the lack of political will to move to a more federal design of the EC. Though he was quite influential in these early years he was unable to push the federal idea further. In the 1980s he masterminded deeper political powers for the European Parliament and sewed numerous seeds in the 1984 Draft treaty establishing the European Union. Some of these would end up in the Single European Act and in the minds of those eventually working on the Maastricht Treaty (Glencross \& Trechsel, 2010; Pinder, 2007).

One such large constitutional moment that could have defined the EU in a way similar to the Philadelphia Convention of 1787, that founded the United States of America (USA), or the British North America Act (BNA), that created Canada in 1867, was the European 
Convention that took place in the early 2000s. The leaders of the Convention, indeed, realized it could be such a foundational moment and took it to the next level. Even though the mandate was relatively modest ${ }^{7}$ they started referring to the entire legal text they were producing as being the creation of a 'Constitution for Europe'. As was mentioned above, the move towards such a constitution was not supported by various groups of citizens. Yet the eventual Lisbon Treaty, that was adopted, was in many ways similar to the Treaty establishing a Constitution for Europe (Verdun 2013). So, in a roundabout way, the Monnet Method, the incremental path, still seems to be working.

Burgess (2006a) says about the EU that "both in its original conception and its subsequent construction the EU has strong federal and confederal elements that coexist simultaneously with equally robust intergovernmental and supranational features" (Burgess, $2006 a$, p. 245). One of the main reasons that there are difficulties recognizing the EU as a federation lies in the state system that recognizes nation-states as sovereign entities. The origin of study of the EU is in international relations (IR)-identifying the relations among member states as relations among sovereign nation states in this state system. In other words, the EU as a model is judged within a context of a world of states. The fact that the member states of the EU are today already considered full-fledged 'states', in this sense, causes problems for the conceptualization of the EU as a federal state with sub-nation-state-level government entities. In the words of Burgess: "In one particular sensethat of inter-state relations characterized by intergovernmentalism - the EU is clearly located in the world of IR that conventionally classifies it as a confederation while in another sense - that of supranationalism - the logic of European integration seems to portend the transcendence and transformation of the national state into a new, overarching, multinational federation. Here it would be a federation of existing, mainly mature, nation states" (Burgess, 2006a. p. 246). In other words, the EU has both federal and confederal components in its political system.

\section{Federalism in Canada}

The creation of the Canadian federation was an elitedriven endeavour. There was not much involvement of a wide range of citizens or representatives of the popu-

\footnotetext{
7 The mandate included: (1) better division and definition of competences; (2) the simplification of the instruments; (3) more democracy, transparency and efficiency in the European Union; and (4) preparing the way for a 'constitution' for the people of Europe (simplification and reorganization of the treaties, inclusion of the Charter of Fundamental Rights and the possible adoption of a constitutional text), see http://europa.eu/scadplus/european_convention/introducti on_en.htm
}

lation. Also, it was not created to overthrow a regime, even if it was aimed at creating a country that was breaking free from British colonialism. Nevertheless the model chosen still married two types of political systems: the British style Westminster model and federalism. In this sense, although both are highly decentralized, the Canadian and the US models are distinct models (Canadian is parliamentary; the US presidential with a nation-wide two-party system). The Canadian model has on occasion led to a domination of a regional party that then gets a say in federal politics in its parliamentary system.

The Canadian federal model can be seen as a multinational federation (Gagnon, 2010, p. 50). This type of federalism provides measures to ensure that the various nations or communities within the federation should have the means to ensure that members of all national communities can achieve similar standards. Multi-national federations do not necessarily manage to ensure similar standards but there can be policies and government structures to achieve this aspiration. In fact, many have argued that the Canadian multinational federation has often missed the boat on accommodating the needs of the various nations within the Canadian federation. It is one reason why there were referendums in Quebec (in 1980 and in 1995) to vote on whether Quebec should secede from Canada. Similarly, if one looks at the socio-economic and political conditions among First Nations communities in Canada, it is clear that they are far from "achieving similar standards", that is, compared to standards elsewhere in Canada (judging by, for instance, infant mortality, literacy, employment levels and life expectancy).

In this sense the constitution of Canada does not accommodate satisfactorily the needs of its nations. As Alain-G. Gagnon has argued, there is a lack of "justice" in the system (Gagnon, 2010, p. 31). With much of the focus on procedural federalism it is possible to overlook the effects these procedural measures might in effect have on minority groups - those that make up a smaller part of the federation compared to the majority group. The critics of traditional liberalism have focused on how this traditional reading does not do justice to "deep diversity" (Taylor, 1993, pp. 181-184). Authors such as Kymlicka and Tully have criticized Canadian federalism indicating how adjustments need to be made in order to support the needs of these minority groups, which could lead to more "asymmetrical" federalism (Gagnon, 2010, pp. 31-51). It should ensure democratic principles are adhered to and that the government levels are accountable by allowing for more political participation and a valuation of the diversity of cultures amongst the citizens that make up the federation. Sensitivity to these matters would ensure longterm stability in the federation.

Federalism in Canada has been labelled as 'executive federalism' (Smiley 1980; Watts 1988, 1989). It de- 
scribes "the relation between elected and appointed officials of the two orders of government" (Smiley, 1980, p. 91). Or as Watts describes it: a process whereby intergovernmental negotiations are dominated by the executives of the different governments within the Canadian federal system (Watts, 1988, p. 3). Much of the way people recently characterised Canadian federalism can be traced back to the leadership style of the Prime Minister (PM). PM Jean Chrétien was seen to meet the Premiers of the provinces if he could have some control of the outcome and in a decade he only met the Premiers seven times (Wells, 2008). PM Paul Martin wanted to meet the premiers more but had a different style of trying to get results out of them. The most recent conservative federal government for ten years under then PM Stephen Harper (2006-2015) had a tendency to focus on its own competence and make decisions independent of a thorough discussion of the matters at the lower level (provinces and territories). In return, provinces and territories have had a tendency to execute policies without much deliberation among the other provinces and territories. Indeed, we have found that institutions that facilitate conversations among first ministers of the provinces and territories ('first ministers conferences') have not been called, as the Harper did not bring the premiers together at all in the last six years of the ten years that he was in office as Prime Minister. The current Canadian PM, Justin Trudeau, has already met his Premiers and, although it is still early days, seems more likely to be keen than his predecessor to include this group (Geddes, 2016; The Star, 2015).

\section{Comparing the EU to Canada}

Turning to a comparison of Canada to the EU we find various interesting overlapping characteristics. If one were to assume that we could compare the two political systems - that is, the European supra-national level could be compared to the federal level in Canada and the level of the member states could be compared to the provinces and territories in Canada-one could come up with the following comparison.

Let us first turn to the Michael Burgess's theoretical insights on federalism in the cases of Canada and the EU. In section 2 we reviewed how a single theory of federalism is still lacking. Across the globe a federal design may be used in cases where there is a process of federalisation, which can be the case when an institutional structure is to be created that seeks to mediate between multinational entities or a diverse territorial space. The European Union had such a moment on different occasions, most recently with the Constitutional Treaty in 2003. Had the Treaty Establishing a Constitution for Europe, signed by heads of state or government, been ratified by all (at the time fifteen) member states, this document would have constituted a found- ing document for the next step in federalisation (cf. Trechsel, 2005). But, as was mentioned above, there is ample evidence that despite the absence of the symbols present in the Constitutional Treaty, the essence of it has been incorporated into the Lisbon Treaty that was ratified. The Canadian equivalent can be found both in the Quebec conference in 1864 (that founded Canada), but also the Charlottetown Accord (1992); the latter aimed at making changes to the Canadian constitution-to settle the division of powers between the federal and provincial governments. This Accord eventually also was defeated in a public referendum in October 1992. What we learn from Burgess is that the building of a federation is a process; just because there have been attempts that failed does not stop it from being part of the federal process.

We looked above at the difference between the concept of federalism and federation (Burgess \& Gagnon, 1993, p. xiii; Gagnon, 2010, p. 3; King, 1982). The latter refers more to institutions; the former is broader and includes traditions, ideology including perhaps the advocacy for an end goal. In the EU context, the more ideological dimension, in fact, is weak. Very few scholars, citizens, and politician wish to invoke 'federalism' as an ideology - a path towards deeper integration. What describes the developments in the EU much better is the concept of 'federalism'. Furthermore, another aspect of federalism, mentioned above, had been the fact that a multinational federation is a vehicle to acknowledge the existence of various nations within the federation and offers a way to accommodate these different minorities (Gagnon, 2010, p. 5). Both Canada and the EU easily fit this characterisation of multinational federation. Each has distinct nations. The EU today has 28 member states; Canada has numerous nations in its midst even though the federal structure only accommodates the provinces and territories and not so much the first nations.

Turning to the more institutional characterisation of federation, the way Canadian federalism has been characterised as 'executive federalism' (Smiley, 1980; Watts, 1988, 1989), which is dominated by intergovernmentalism, is a characterisation that would fit well as a descriptor of the way the EU is governed. Even with the recent financial crisis, the subsequent economic crisis, the sovereign debt crisis and the most recently the migration crisis, the EU's mode of governance seems dominated by deliberative intergovernmentalism (Bickerton, Hodson, \& Puetter, 2014). Notwithstanding this descriptor of intergovernmentalism (or 'executive federalism'), the EU did end up creating a number of supranational (read: federal) institutions (Gocaj \& Meunier, 2013; Verdun, 2015b) as well as permit one of its federal institutions, the European Central Bank, to play a more prominent role in dealing with the various crises (Hodson, 2013).

Furthermore, in Canada there is a clear distinction 
between the competence of the federal level and that of the provincial/territorial level. In the EU context we see a similar distinction in a number of policy-making areas. Let us turn to a few policy areas. One of the policy areas in both Canada and the EU for which responsibility lies with the federal/supranational level of governance is international trade policy. Both in the EU and in Canada customs, tariffs, quantitative restrictions and trade agreements are the responsibility of the highest government level. In Canada, day-to-day policy-making in the area of trade policy is done by a federal department recently renamed into 'Global Affairs' (that was in 2013-2015 called the Department of Foreign Affairs, Trade and Development and before July 2013 that it was for many years called 'the Department of Foreign Affairs and International Trade'); in the EU the European Commission counterpart is the Directorate General 'Trade'. Decisions on international trade agreements, such as the recent 'political agreement' on the Comprehensive Economic Trade Agreement (CETA) between Canada and the EU in October 2013, were decided upon by Prime Minister Stephen Harper of Canada and José Manuel Barroso, then President of the European Commission (see also D'Erman, 2016).

It is remarkable that the EU has focused so much on "completing the internal market". One of the strongest drivers of integration in the past four decades has indeed been this goal. The Canadian case is less focused on this same goal. In fact, one could easily find examples of the Canadian internal market having more impediments to mobility than does the European Union market in those similar cases. For instance, taking a bottle of alcohol from one province to another could mean one encounters obstacles at the 'border' between the provinces. ${ }^{8}$ There are also other regulations that need to be put in place to improve the mobility across the Canadian internal market (Internal Trade Secretariat, 2014). These have not been given priority in Canada despite the federal government's goal to sign international trade agreements to enhance free trade across the Canadian border with other nations. Yet the negotiators of the CETA agreement in Canada have noted that these negotiations with the EU have put pressure on Canadian provinces to remove barriers to (internal) trade (Quiring, 2016).

Another typical federal policy is monetary policy (cf. McKay, 2001). The Bank of Canada sets interest rates for all of Canada, for its currency: the Canadian dollar. In the EU context, not all member states are members of the euro area, but those that are face a similar 'supra-national' policy to its Canadian counterpart. In the EU context the European Central Bank (ECB) executes monetary policy (sets interest rates for the euro area).

\footnotetext{
8 Although a New Brunswick Provincial Court judge recently dismissed restrictions on intra-Canada cross-border alcohol allowances for personal as unconstitutional (CBC, 2016).
}

National central banks do not have authority to set their own individual policies insofar as the currency is concerned.

Though monetary policies are unified for the member states that have joined the euro area, flanking policies, such as fiscal policy and the role of what would be the federal ministry of finance are different in the EU. Within EU economic and monetary union (EMU) these policies remain firmly secure at the member state level, even if there are some rules put in place that aim to have the effect that they will lead to a coordination of budgetary and fiscal policies (Heipertz \& Verdun, 2010). Furthermore, the EU supra-national level also only has a fraction of the budget of what the Canadian federal government has to spend, seen that the EU only has a supranational budget of one per cent of Gross Domestic Product. On the flip side, most EU member states have national budgets that are higher than what Canadian provinces and territories spend. Other policy areas are mainly the responsibility of lower level governments in both political systems: education, social policy, health, local infrastructure and so on (Verdun \& Wood, 2013a, 2013b). These few examples indicate how there are similarities between both systems that make it not too far-fetched to imagine that the EU and Canada are in a number of ways similar to each other in their type of multi-level governance.

In terms of institutional comparisons, both Canada and the EU have a parliament at the federal/supranational level. The parliament in Canada is one based on the Westminster model. In Europe the European Parliament (EP) has over time acquired more powers (since 2009, with the entering into force of the Lisbon Treaty, it is now the 'normal' procedure in the EU to need approval from the EP for legislative acts to become law). Although the EP has that 'normal' function for passing most EU legislative acts, the EP is atypical in other ways: parliamentary political party groupings are still more an amalgamation of national parties, that 'sit' together by familiarity rather than a proper, coherent, political party with a unified focus (see also Kreppel, 2006, for an analysis of the EP as a federal body). Similarly, other EU supra-national institutions resemble those in federal states: the Court of Justice of the European Union is the highest court of appeal for EU law and in that way is a court similar to the supreme court of Canada (O'Brien, in press). Nevertheless, the Court of Justice of the EU does not have the power to decide over matters that cannot be traced back to some kind of legal basis in EU treaties (this means that laws that originate in member states and are not regulated by EU law, cannot be brought before the Court of Justice of the EU). Finally, the European Commission in a number of ways resembles a supra-national or 'federal' government. It has directorate-generals that resemble the ministries. Yet the political body of commissioners have not been brought forward through elections in 
the parliament. Rather those candidates are brought forward by the member states governments without there being a formal link to the political background of these candidates-meaning that the proposed commissioner would not necessarily have the same political affiliation as the government of the day. Moreover, the European Commission does not run on a political platform but rather offers services as if there were no political mandate for the period of its duration in office.

Of course, there are indicators that make the two polities very different: EU citizens identify more with the national, regional and local levels than they typically do with the supra-national level. Many Canadians identify just fine with Canada although some minority groups (First Nations; some Quebecers) less so. Having said that, it is noteworthy that the EU citizens tend to trust their European level institutions more than their national level institutions, and this trend has been going on for a number of years (see Figure 1), although most recently trust in European Union institutions is falling quicker than trust in national parliaments and national governments.

All in all, the case can be made that both the European Union and Canada have supra-national/federal characteristics that are similar, even if a number of profound differences remain.

The relations between Quebec and Canada have put significant pressure on the Canadian federation even if Canadian federalism has been "one of the most resilient and enduring of modern federations" (Burgess, 1990, p. 1). Looking at this case through the work of Burgess has shown us that Canadian federalism's strength lies in the way centripetal and centrifugal forces offset one another. Canadian federalism has managed, even if often imperfectly, to accommodate the needs of minorities (in particular the prominent Quebec nation), thus making the centralising forces ultimately have the upper hand. Recent political developments in Canada reflect these insights as the outcome of elections both provincially and federally can be interpreted to mean that there is very limited appetite at the moment in another referendum on Quebec separation. What still needs more attention is the relationship with First Nations, a group of minorities that is still dissatisfied with its status and living standard within the federation. This relationship is one that needs continuous attention and a correction of historical wrongs.

\section{Conclusions}

This article started off examining the concepts of federalism and federation drawing in particular on the work of Michael Burgess. The Europeanist literature offers different insights into when we might call the EU a federation. As of yet very few scholars offer the conclusion that the EU has already met the threshold that the EU could indeed be called a federation. Its leading political bodies still miss the autonomy that is typically attributed to the highest political body; its citizens are not yet identifying with the EU and are not in all bodies directly represented.
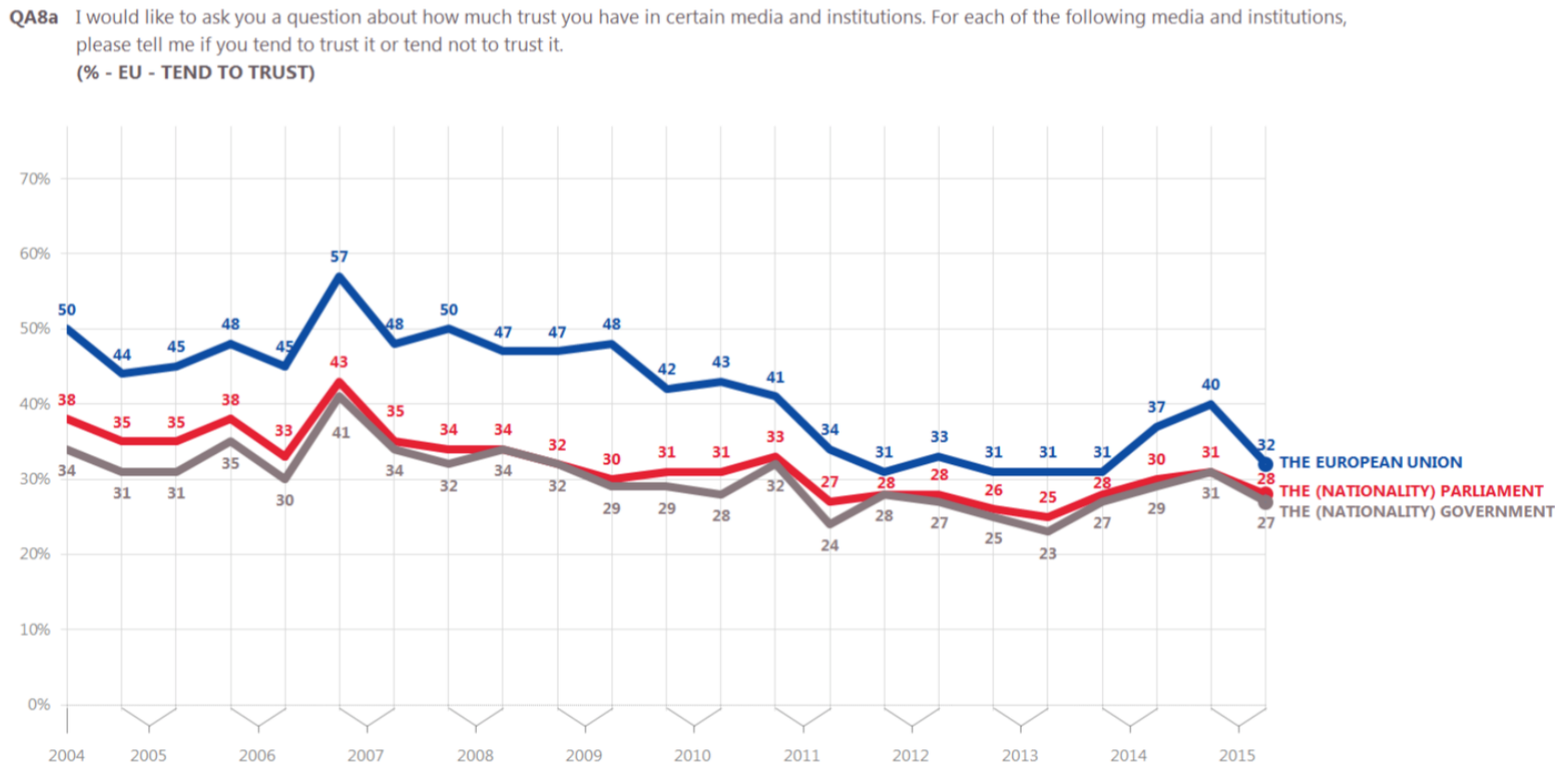

Figure 1. Trust in institutions: EU, national parliaments and national governments. Source: European Commission (2015, p. 8). 
Nevertheless, what we have learnt from this study is that numerous types of federations exist over time and space. It does not do any of them justice to try to define the terms federalism and federation in a rigid fashion. With the help of the comparative work of Burgess we are able to identify building blocks that contribute to an understanding of the specific type of federation in a given time and space. In the cases of Canada and the EU, Burgess's insights prove very helpful indeed. By focusing at once at the institutional, administrative and governmental sides of the equation we are able to see how some federations use division of labour of who is responsible for what part of the tasks and thus have federalism be 'executive' or 'administrative'. On the other side of the equation it is important to realize that federations are made up of different groups, sometimes differing in size, identification, social and political needs and thus simple territorial federalism might not work; one needs multi-level federalism to accommodate diverse groups.

Burgess's work thereby is ideally suited to examine the case of the EU. Although there are hardly any scholars who would openly state that the EU today resembles a pseudo federation, with the help of Burgess's insights we can point to the federal features of the EU. Comparing the EU to the case of Canada is attractive. Canadian federalism is quite decentralized and 'confederal', multinational, and 'executive' so that some comparisons are actually striking. Many have argued that the EU is a sui generis political system. But in comparing the nature of the Canadian federation to that of the EU enables us to look beyond the specific sui generis characteristics of the EU. It offers us a toolkit that facilitates a comparison with other polities that in turn can offer us insights into what goes on within the EU political system. Such an analysis enables us to see that the EU is in fact already on a clear federal path. Even if it has not been a big bang, its incremental steps can clearly be identified as having federal characteristics. In other words, the EU has a considerable amount of federal features (federation), but that a federal tradition, a federal ideology and advocacy to a federal goal (federalism) are mostly absent.

\section{Acknowledgments}

The author thanks Alain-G. Gagnon, Soeren Keil and Sean Mueller as well as Reeta Tremblay and Donna Wood for encouraging her to produce this article, that builds on, and is inspired by, Verdun (2015a). The author thanks anonymous reviewers of this journal for helpful comments and criticisms on earlier versions of this article. Any remaining errors are that of the author.

\section{Conflict of Interests}

The author declares no conflict of interests.

\section{References}

Bickerton, C., Hodson, D., \& Puetter, U. (2014). The new intergovernmentalism: European integration in the post-Maastricht era. JCMS: Journal of Common Market Studies, 53(4), 703-722. doi:10.1111/jcms.12212

Borrell, J. (2015, February 22). Is a federal Europe possible? The New Federalist. Retrieved from http://www. thenewfederalist.eu/is-a-federal-europe-possible

Börzel, T. (2005). What can federalism teach us about the European Union? The German experience. Regional and Federal Studies, 15(2), 245-257.

Börzel, T., \& Hosli, M. (2003). Brussels between Bern and Berlin: Comparative federalism meets the European Union. Governance, 16(2), 179-202.

Bryce, J. (1928). The American commonwealth. New York: Macmillan.

Burgess, M. (1989). Federalism and European Union: Political ideas, influences, and strategies in the European Community, 1972-1987. London: Routledge.

Burgess, M. (Ed.). (1990). Canadian federalism: Past, present, and future. Leicester: Leicester University Press.

Burgess, M. (1995). The British tradition of federalism. Madison, NJ: Fairleigh Dickinson University Press.

Burgess, M. (Ed.). (1986). Federalism and federation in western Europe. London: Croom Helm.

Burgess, M. (2000). Federalism and European Union: The building of Europe, 1950-2000. Oxon: Routledge.

Burgess, M. (2006a). Comparative federalism: Theory and practice. London: Routledge.

Burgess, M. (2006b). Territoriality and federalism in the governance of the European Union. In M. Burgess \& H. Vollaard (Eds.), State territoriality and European integration: Territoriality and federalism in EU governance (pp. 100-119). London: Routledge.

Burgess, M. (2012). In search of the federal spirit: New comparative empirical and theoretical perspectives. Oxford: Oxford University Press.

Burgess, M., \& Gagnon, A. (Eds.). (1993). Comparative federalism and federation: Competing traditions and future directions. Toronto: University of Toronto Press.

CBC. (2016). New Brunswick judge throws out crossborder booze limits. Provincial court judge says alcohol rules violate Constitution's free-trade provisions. CBC. Retrieved from http://www.cbc.ca/news/ canada/new-brunswick/gerard-comeau-border-alco hol-ruling-1.3554908

D'Erman, V. J. (2016). Comparative Intergovernmental Politics: CETA Negotiations between Can-ada and the EU. Politics and Governance, 4(3), 90-99.

Duchêne, F. (1994). Jean Monnet: The first statesman of interdependence. New York: Norton.

Duff, A., Pinder, J., \& Pryce, R. (Eds.). (1994). The Maastricht treaty and beyond: Building the European Union. London: Routledge. 
European Commission. (2015). Standard Eurobarometer No. 84. Retrieved from http://ec.europa.eu/COMM FrontOffice/PublicOpinion/index.cfm/Survey/getSurv eyDetail/instruments/STANDARD/surveyKy/2098

Fabbrini, S. (Ed.). (2005). Democracy and federalism in the European Union. Exploring post-national governance. London: Routledge.

Fossum, J.-E. (2006). Conceptualizing the European Union through four strategies of comparison. Comparative European Politics, 4, 94-123.

Freeman, E. A. (1892). History of federal government in Greece and Italy (2nd ed.). Retrieved from https:// archive.org/details/cu31924030430932

Gagnon, A.-G. (Ed.). (2010). The case for multinational federalism. London: Routledge.

Gagnon, A.-G., Keil, S., \& Mueller, S. (Eds.). (2015). Understanding federalism and federation. London: Ashgate.

Geddes, J. (2016, March 2). Off to a tense start: Justin Trudeau meets the premiers. Maclean's. Retrieved from http://www.macleans.ca/politics/ottawa/offto-a-tense-start-justin-trudeau-meets-the-premiers/

Glencross, A. (2009). Altiero Spinelli and the idea of the US constitution as a model for Europe: The promises and pitfalls of an analogy. JCMS: Journal of Common Market Studies, 47(2), 287-307.

Glencross, A., \& Trechsel, A. (Eds.). (2010). EU federalism and constitutionalism - The legacy of Altiero Spinelli. Plymouth: Lexington Books.

Gocaj, L., \& Meunier, S. (2013). Time will tell: The EFSF, the ESM, and the euro crisis. Journal of European Integration, 35(3), 239-253.

Griffiths, R. (2012). The founding fathers. In E. Jones, A. Menon, \& S. Weatherill (Eds.), The Oxford handbook of the European Union (pp. 181-192). Oxford: Oxford University Press.

Heipertz, M. \& Verdun, A. (2010). Ruling Europe: The politics of the stability and growth pact. Cambridge, UK: Cambridge University Press.

Hobolt, S. (2006). Direct democracy and European integration. Journal of European Public Policy, 13(1), 153166.

Hodson, D. (2013). The Eurozone in 2012: Whatever it takes to preserve the euro? JCMS: Journal of Common Market Studies, 15, 183-200.

Hosli, M., Kreppel, A., Plechanavová, B., \& Verdun, A. (Eds.). (2015). Decision-making in the EU before and after the Lisbon treaty London: Routledge.

Hueglin, T. (2013). Treaty federalism as a model of policy making: Comparing Canada and the European Union. Canadian Public Administration, 56(2), 185-202.

Internal Trade Secretariat. (2014). Canada's evolving internal market: An agenda for a more cohesive economic union. Retrieved from http://www.ppforum. $\mathrm{ca} /$ publications/canada's-evolving-internal-marketagenda-more-cohesive-economic-union

Joerges, C. (2005). Rethinking European law's supremacy
(EUI Working Paper LAW No. 2005/12). Retrieved from http://papers.ssrn.com/sol3/papers.cfm?abstra ct_id $=838110$

Kelemen, R. D. (2003). The structure and dynamics of EU federalism. Comparative Political Studies, 36(1-2), 184-208

Kelemen, R. D. (2007). Built to last? The durability of EU federalism. In S. Meunier \& K. McNamara (Eds.). Making history: European integration and institutional change at fifty (pp. 51-66). Oxford: Oxford University Press.

King, P. (1982). Federalism and federation. Baltimore: Johns Hopkins University.

Kreppel, A. (2006). Understanding the European parliament from a federalist perspective: The legislatures of the United States and the European Union compared. In A. Menon \& M. Schain (Eds.), Comparative federalism: The European Union and the United States in comparative perspective (pp. 245-271). Oxford: Oxford University Press.

McKay, D. (2001). Designing Europe. Comparative lessons from the federal experience. Oxford: Oxford University Press.

Menon, A., \& Schain, M. A. (Eds.). (2006). Comparative federalism. The European Union and the United States in comparative perspective. Oxford: Oxford University Press.

O'Brien, M. (in press). Legal integration and the court of justice of the European Union. In E. Brunet-Jailly, A. Hurrelmann, \& A. Verdun (Eds.), European Union governance and policy making -A Canadian perspective. Toronto: Toronto University Press.

Parliament of Canada. (2016). How Canadians govern themselves-Canadian and American government. Retrieved from http://www.lop.parl.gc.ca/About/Parl iament/senatoreugeneforsey/book/chapter_4-e.html

Phelan, W. (2012). What is sui generis about the European Union? Costly international cooperation in a self-contained regime. International Studies Review, 14(3), 367-385.

Pinder, J. (2007). Altiero Spinelli's European federal odyssey. The International Spectator: Italian Journal of International Affairs, 42(4), 571-588.

Quiring, J. (2016, February 18). Comprehensive economic and trade agreement (CETA) between Canada and the European Union. Paper presented at the public discussion "CETA: Opportunities and Challenges for British Columbia", Victoria, Australia.

Riker, W. (1964). Federalism: Origin, operation, significance, Boston: Little Brown.

Sidgwick, H. (1891). The elements of politics. London: Macmillan.

Simeon, R. (2006). Federal-provincial diplomacy. Toronto: University of Toronto Press.

Smiley, D. V. (1980). Canada in question: Federalism in the eighties. Toronto: McGraw-Hill Ryerson.

Taylor, C. (1993). Reconciling the solitudes: Essays on 
Canadian federalism and nationalism. Montreal: McGill-Queen's University Press.

The Star. (2015). Trudeau reaches out to premiers. The Star. Retrieved from http://www.thestar.com/news/ federal-election/2015/09/02/trudeau-reaches-outto-premiers.html

Tömmel, I. (2011). The European Union-A federation sui generis? In F. Laursen (Ed.), The EU and federation: Polities and policies compared (pp. 41-56). Farnham: Ashgate.

Trechsel, A. (2005). How to federalize the EU...and why bother. Journal of European Public Policy, 12(3):401418.

Triandafyllidou, A., \& Gropas, R. (2015). What is Europe? Houndmills: Palgrave-Macmillan.

Ugland, T. (2011). Jean Monnet and Canada: Early travels and the idea of European unity. Toronto: University of Toronto Press.

Verdun, A. (2013). Decision-making before and after Lisbon: The impact of changes in decision-making rules. West European Politics, 36(6), 1128-1142.

Verdun, A. (2015a). Federalism in the EU and Canada. In A.-G. Gagnon, S. Keil, \& S. Mueller (Eds,), Understanding federalism and federation (pp. 233-244). London: Ashgate.

Verdun, A. (2015b). A historical institutionalist explanation of the EU's responses to the euro area financial crisis. Journal of European Public Policy, 22(2), 219237. doi:10.1080/13501763.2014.994023

Verdun, A. \& Wood, D. (Eds.). (2013a). Governing the social dimension in Canadian federalism and European integration. Canadian Public Administration, 56(2), 171-366.

Verdun, A., \& Wood, D. (2013b). Governing the social dimension in Canadian federalism and European integration: An introduction. Canadian Public Administration, 56(2), 173-184.

Wallace, W. (1983). Less than a federation. More than a regime: The community as a political system. In $\mathrm{H}$. Wallace \& W. Wallace (Eds.), Policy-making in the European Community (pp. 403-436). Oxford: Oxford University Press.

Watts, R. L. (1988). Executive federalism: A comparative analysis. Kingston, Ontario: Institute of Intergovernmental Relations.

Watts, R. L. (1989). Comparing federal systems (2nd ed.). Kingston, Ontario: Institute of Intergovernmental Relations, Queen's University.

Wells, P. (2008, November 10). Harper and the death (for now) of executive federalism. Maclean's. Retrieved from http://www.macleans.ca/politics/ ottawa/stephen-harper-and-the-death-for-now-ofexecutive-federalism

Wolinetz, S. B. (2011). Comparing the incomparable: Treating the EU in comparative context. In F. Laursen (Ed.), The EU and federalism (pp. 27-39). Farnham: Ashgate.

Wood, D., \& Verdun, A. (2011). Canada and the European Union: A review of the literature from 1982 to 2010. International Journal, 66(1), 19-21.

\section{About the Author}

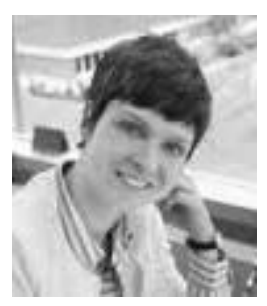

Amy Verdun is Professor of Political Science and Jean Monnet Chair Ad Personam in the Department of Political Science at the University of Victoria, Canada. She has published 18 books, more than 120 peer-reviewed articles and chapters on various aspects of European integration. Her articles have come out in journals such as International Studies Quarterly, Journal of European Public Policy, Review of International Political Economy, West European Politics, and World Politics. She is the coeditor of JCMS: Journal of Common Market Studies. 